\title{
The Peculiarities of Civil-Legal Regulation of Transplantation in Ukraine and Europe
}

\author{
Alla Herts \\ Civil Law and Legal Proceedings Department, \\ Ivan Franko National University of Lviv, \\ Sichovykh Striltsiv 14, \\ Lviv 79000, Ukraine \\ E-mail:agerc@ukr.net
}

Abstract: In modern realities the issue of the quality and accessibility of health services, the cost of medicines, examinations and treatment in general is being increasingly frequently discussed. The attention is focused on such a narrow surgical field as transplantation, because in Ukraine thousands of patients are waiting in line for organ transplantation and very few operations are performed. The main, most secure and common type of transplantation is the transplantation of organs and tissues from a deceased person, the dead body. Cadaveric transplantation, which is used in most developed countries, is hardly carried out in Ukraine. This is due to the fact that the current regulatory base of Ukraine in the field of transplantation does not fully meet the needs of modern medicine and has many gaps. The aim of donation is a future transplantation (including and in cases of blood transfusion and reproductive cells use). The parts (tissues, organs, their parts, individual cells) extracted (separated) from the body in the process of donation can be used generally in the treatment process in a processed form (blood plasma) or in the original state (fertilized reproductive cells). The detailed analysis of the provisions of the national legal system makes it possible to conclude that, despite the absence of direct regulation of relations concerning organ donation and transplantation as material relations, the legal regulations provide the fundamental provisions, which determine their material nature, and therefore offer opportunities for agreementbased regulation. In our opinion, one of the essential legal means of ensuring the rights of participants in the relations of donation 
and transplantation can be their agreement-based regulation. The peculiarities of civil-legal regulation of transplantation in Ukraine and Europe are simultaneously analysed; and the grounds of its legitimacy are defined.

Keywords: blood and blood components donation, civil-legal regulation of transplantation, the right of donation, transplantation of organs and other anatomical materials

\section{Introduction}

Since its very establishment, transplantology has posed many questions of a legal nature which have not been solved in the process of the society's development. The need for adequate legal basis of transplantation is associated primarily with the special relationship between a donor and recipient, the specifics of which is based on the equal right to life for each of them. The guarantee of fundamental rights and freedoms of citizens and, above all, the right to life is an indicator of the state's civilization.

For the first time transplantation has addressed an ethical and legal issue for the legislator - the relationship between two persons: the patient (the recipient) whose life and health depends directly on the fact of organ or tissue transplantation from another person - the donor (living or deceased).

In 1932, the Ukrainian doctor Yuriy Voronyi performed kidney transplantation for the first time in the world. O. Nikonenko marks: "No matter where you come from, we are called the transplantation originators, and we were the originators and we continue to be the originators: we remain behind the developed countries for about 30 years" (Moiseieva, 2015).

Historically, the regulation of relations in medicine was carried out in accordance with ethical standards, but progress in transplantation demanded more perfect regulation in this sphere. The development and improvement of legal relations in the field of transplantation is still ongoing today, along with new achievements in medical and legal sciences, and that is why this process is continuing.

The low awareness of people about the benefits of organ transplantation for saving human life, the lack of guarantees of patients' rights at conducting such operations, the preservation of the "presumed consent" at the legislative level at obtaining donor organs, held Ukraine back on square one in conducting organ 
transplant operations. It is beyond argument that the solution of the abovementioned issues is impossible without improving the legislation of Ukraine in the field of donating organs and transplantation.

This study analyses such issues as the rights for donating organs; defines a system of agreements that mediate the relationships between donation and transplantation; and reveal the peculiarities of the legal status of the parties in contractual relations in the field of organ transplantation.

The system of scientific principles and the dialectical method of cognition makes up the methodological basis of the study.

The general scientific methods were used: formal-legal, comparative-legal, as well as special scientific methods of logical, system-structural and comparative analysis, which were jointly used to clarify the civil-legal regulation of transplantology in Ukraine and Europe.

\section{Results of the research}

The legal basis of relations of transplantology in Ukraine makes up a system of laws, sub-legislative regulatory and international law acts regulating the relations in this sphere. The need for an adequate legal basis of transplantation is associated primarily with the special relations between a donor and a recipient, the specifics of which are based on the equal right to life for each of them. The guarantee of fundamental rights and freedoms of citizens and, above all, the right to life is an indicator of the state's civilization (Kerikmäe et al., 2016), which is why in the developed countries the transplantation of organs and tissues is regulated by the relevant regulatory acts.

The legislation of Ukraine provides the right to donate or some of its structural elements, particularly in the Civil Code of Ukraine (Art. 281, p. 7, Art. 290), in the Law of Ukraine 'The Fundamentals of the Legislation of Ukraine on Health Care' of 19 November 1992 (Art. 46, 47, 48), in the Law of Ukraine 'On Transplantation of Human Organs and Other Anatomic Materials' of 16 July 1999, in the Law of Ukraine 'On the Blood and Blood Components Donation' of 23 June 1995, in the Law of Ukraine 'On the Prohibition of Human Reproductive Cloning' of 14 December 2004, and also in the sub-legislative regulatory acts that determine certain issues in donation sphere, among which the important place is occupied by the 'Instruction on the Donor Organ Recovery from a Dead Donor', approved by the order of the Ministry of Health of Ukraine 
on 25 September 2000 (No. 226), 'Instruction on the Removal of Structures, Tissues, their Components and Fragments from a Dead Donor', approved by the order of the Ministry of Health of Ukraine on 25 September 2000 (No. 226), the list of measures to prevent the transmission of infectious diseases at the transplantation of organs and other anatomical materials to a human, approved by the order of the Ministry of Health of Ukraine of 10 June 2004 (No. 294), Order No. 155.24 of 12 March 2009. On approval of the instruction of measures of the Ministry of Health and Academy of Medical Sciences of Ukraine on the implementation of the State Target Social Program 'Transplantation' for the period up to 2012, the Order of the Ministry of Health of Ukraine 'On Approval of the Terms and Conditions for the Application of Artificial Insemination and Implantation of the Embryo (Embryos) and Methods of their Implementation' (No. 24) of 04 February 1997.

By the Order of the Ministry of Health of Ukraine of 27 April 1994 (No. 257) was established the Coordination Centre for the Transplantation of Organs, Tissues and Cells, which is the main scientific and practical institution that organizes and conducts clinical tests of tissue and cell transplants at the expense of voluntary contributions from legal entities and individuals, other sources not prohibited by law; carries out control over the activities of health facilities and scientific institutions, regardless of their subordination, related to the transplantation of organs, tissues and cells ('On the Approval of the Regulation on the Coordination Centre for the Transplantation of Organs, Tissues and Cells', 2006).

Among the international law acts which regulate the transplantation performance we should distinguish such acts as the Convention for the Protection of Human Rights and Dignity of the Human Being with regard to the Application of Biology and Medicine: the Convention on Human Rights and Biomedicine of 4 April 1997, the Regulation on the transplantation of fetal tissues, adopted by the 41st World Medical Assembly in September 1989, the Declaration on transplantation of human organs, adopted at the 39th World Medical Assembly in October 1987, 'The Basic Principles of Human Organs Transplantation', adopted by the World Health Organization in 1991, Resolution 'On Prohibition of Human Organs Purchase-Sale', adopted in 1989 at the 42nd Assembly of WHO.

Since 1999, the practical activity of the Transplant Service of Ukraine has been regulated by the Law of Ukraine 'On the Transplantation of Human Organs and Other Anatomic Materials' (1999), adopted on the basis of the current state of research and the recommendations of the World Health Organization to determine the conditions and procedure for use of transplantation as a special treatment method. The Draft Law of Ukraine 'On Organ Transplantation and Other 
Anatomical Materials to a Human' of 4 August 2015 ('On the transplantation of human organs and other anatomical materials,'2015) stipulates that every adult legally capable person can give written consent to become a donor of organs and/or anatomical materials after their death. After giving permission, a card of a potential donor of a state standard is drawn up for such person. The Government of Ukraine further has to elaborate and approve the entire procedure on giving consent, of a single sample and procedure for issuing a card of a potential donor, recording the information about the persons who gave such consent to the Unified State Information System of Transplantation. The information on such consent will be treated as confidential. Also, the draft law stipulates that the statement of giving a permit for transplantation may be revoked. The law will introduce new standards for regulation of transplant-related activities in Ukraine, change the system of state control, and increase the level of protection of information about donors and recipients. At every health care institution accredited by the Ministry of Health of Ukraine, specialized transplant departments will be established according to the international standards.

It is worth emphasizing that all the major international instruments that regulate the issue of transplantation of organs and tissues, stipulate the prohibition of transplantation commercialization (Declaration concerning the human organs transplantation, 1987; Provision on sale of live organs adopted by the 37th World Medical assembly Brussels, 1985; Convention for the Protection of Human Rights and Dignity of the Human Being with regard to the Application of Biology and Medicine: the Convention on Human Rights and Biomedicine, 1997). Article 18 of the Law of Ukraine 'On the Transplantation of Human Organs and Other Anatomic Materials' validates the provisions whereby the agreements which stipulate the sale of organs or other anatomic human materials, with the exception of bone marrow, is prohibited and serves as a guarantee of compliance with this international legal standard in the national legislation. If the sources mention the cost of transplantation, such as the heart transplantation, it states not about the cost of the organ, but about the payment of medicines, the service expenses, etc.

In juridical literature the general view has been expressed that the commercial use of organs should be criminally liable. Article 5 of the Law of the Republic of Belarus 'On the Transplantation of Human Organs and Tissues' (1997) contains similar provisions that human organs and tissues cannot be the object of civillegal operations, except for the operations that are uncompensated. 
The prohibition of commercial use of donor organs has effect in most countries of the world, but the commercial relations in transplantation exist. This is because the medical facility that performs extraction becomes the owner of the transplant material with expected consequences and actions for it (medical facility) as the subject of the whole complex of relations arising in the treatment of donor organs and tissues (Volkova, 2011, pp. 100-105).

Thus, the problem of fee-based or free organ donation is associated primarily with the definition of the legal regime of the transplants - organs and tissues, extracted from the donor's body. These biological materials are the object of transplantation.

It should also be noted that a way of obtaining organs for transplantation is the cloning of such organs. Cloning can be defined as the process of creating identical copies (replication) of organisms and other objects. Within the meaning of medicine, cloning can be divided into two main categories - reproductive and therapeutic. Reproductive cloning is cloning intended for the birth of a living person, against which all governments and most people act. Therapeutic cloning is the cloning for other goals than the birth of a human and it has received support from various governments and many people (Pynes, 2009).

It is worth agreeing with I. R. Ptashnyk, who in her work entitled Civil Regulation of Transplantation in Ukraine states that the alternative ways of obtaining organs for transplantation should be considered as: an artificial creation of organs, growing of organs from embryonic stem cells, and cloning of organs. The legal regulation of the activity in creation of artificial and/or cloned organs is suggested to be carried out by concluding an agreement on the creation (cloning) of an organ. (Ptashnyk, 2016)

The transplantation of organs and tissues is fundamentally different from other methods of traditional treatment, first of all, by the subject composition. Apart from a medical service provider - a specialized medical institution authorized to carry out the relevant surgical operations and a patient-recipient, who, for medical reasons, needs the organ (tissue) transplantation to save the life, in the relations of transplantation there is also a donor, whose expression of will is critical for transplantation.

Thus, instead of the normal legal relations that arise between the two subjectsthe medical service provider and patient — at transplantation more complex legal relationship occurs, where at the first phase the participants are a donor and medical service provider, and later - a medical service provider and recipient. 
In the context of the above-mentioned material it is necessary to consider more thoroughly the issues such as the right of donation. According to Article 290 of the Civil Code of Ukraine, a full-aged capable physical person is eligible fot donating blood, blood components and organs and other anatomical materials and reproductive cells. This donation is carried out according to the lawthis special law is the Law of Ukraine 'On the Blood and Blood Components Donation' (1995). This law contains a great number of inconsistencies regarding the European legislation.

These contradictions are systemic in nature and make it impossible to comply with the European standards. These include the absence of definitions of such terms as 'organ', 'tissue', 'human use', 'tissue bank', 'serious adverse event' and so on. The law does not take into account the requirements of Article 12 of Directive No. 2004/23/EU (2004, pp. 10-12) on ensuring the compliance with EU legislation of incentive or public measures to support the donation of human tissues and cells. The requirements for the suitability of blood and plasma donors, in particular their age, are not taken into account, because the donor must be at least 18 and no older than 65 . There are also restrictions on donation after age 60 and after 65 (Annex II of Recommendation No. 98/463/ EU [3, Annex 2]). In the experts' opinion, there are inconsistencies in the field of guarantee of the donors' anonymity, too.

Similar provisions prevent the implementation of international standards of blood certification, its subsequent verification by these standards and safety provision at blood transfusions.

Article 290 of the Civil Code of Ukraine is structured in such a way as to emphasize the importance of preserving human life by means of donation. From the public point of view the preference should be given to the health of a living person, though it should also respect the memory of the deceased, which includes their physical integrity after death. In case of a physical person's death, their family members or other individuals authorized by them have the right to be present at the study of their causes of death and view the findings on the death causes, and have the right to appeal these findings in the court. The said right is stipulated under Article 285 of the Civil Code of Ukraine (2003), which is a constituent part of another right - the right to health care.

As for the transplantation procedure itself, it is necessary to follow both medical and legal requirements. The examination of the recipient's state of health is a medical act which must meet the legal criteria for eligibility of the recipient to the transplantation for health reasons - namely, such state of health which 
ensures that with the favourable prognosis for transplantation, their health will greatly improve and they will retain the ability of other organs to perform their functions. The recipient's consent for organ transplantation into his/her body is a subsequent important prerequisite for transplantation, and the consent must be given in writing. Otherwise the transplantation is unacceptable (Approving Instructions on extraction of human organs from a dead donor body, 2000).

In addition to the expression of will, the following conditions have to be met: full awareness of the risk and possible consequences of transplantation; complete freedom and independence in making decisions; the recipient's capability. In case of the recipient's incapacity or limited capacity, his/her legal representative gives consent.

The donor's consent is a condition without which it is impossible to extract the organ from his/her body. It has the same conditions as for the recipient's consent. The donor's suitability according to the state of health is the next prerequisite for carrying out transplantation. His/her state of health shall ensure that at the transplantation of the organ, extracted from his/her body, the recipient's health will not be in danger; the patient will not be infected from the donor and vice versa. In the case of implantation of organs and other anatomical materials, the donor's family members or close relatives have the right to know the recipient's name.

Article 290 of the Civil Code of Ukraine assignes to a full-aged capable physical person the right to be a blood and blood components donor. According to Article 46 of the Fundamentals of Legislation on Health Care and Article 2 of the Law of Ukraine 'On the Blood and Blood Components Donation', blood and blood components donation is a voluntary act of the person's expression of will that involves giving blood or blood components for further direct use in scientific research. The development of blood and its components' donation is considered to be an important socially necessary matter of the state.

The detailed analysis of the provisions of the national legal system makes it possible to conclude that, despite the absence of direct regulation of relations concerning organ donation and transplantation as material relations, the legal regulations provide the fundamental provisions which determine their material nature, and therefore offer opportunities for agreement-based regulation. In our opinion, one of the essential legal means of ensuring the rights of participants in the relations of donation and transplantation can be their agreement-based regulation. Intangible benefits as objects of the corresponding subjective rights of a person are closely associated with a person. By its content they are 
inseparable from a person, are associated with the subject's personality, and are not the subject to be alienated in any form. Unlike material benefits, they cannot be sold, donated or exchanges (Antipov, Barinov \& Bykova, 1998). The agreements aimed at the disposal of these rights are impossible; any alienation of these rights (paid or free of charge) is unacceptable. These rights lose its reason for existence beyond the organic relationship with their holder (Voloshyn \& Ryasentsev, 1987).

At the same time, foreign juridical literature states that human body parts, organs and blood after their extraction are the objects of civil rights (Welser \& Rabl, 2004).

It is confirmed that in case of the realization of the right of donation there is no alienation of the right to health, but the alienation of a separate part of a human body. These rights are closely interconnected. The realization of one is impossible by restricting the other right. The right to health does not lose its meaning, because health benefit continues to exist.

Thus, the goal of donation is a future transplantation (including and in cases of blood transfusion and reproductive cells use). The body parts (tissues, organs, their parts, individual cells) extracted (separated) in the process of donation can be used generally in the treatment process in a processed form (blood plasma) or in the original state (fertilized reproductive cells).

Therefore, during the donor operations, the following transformations are carried out: the extraction of certain anatomical material that is a part of the body, in other words, is a part of the material world. Donors are not deprived of health benefit, this benefit is not limited.

Blood, acting as an element of material base of intangible health benefits and eventually — of life benefit, in its turn, is a material phenomenon itself and that is why it can legally be sold, donated or exchanged.

We believe that the blood and blood components donation as a medical service should be fee-paid. Certain services, such as purchasing, storage and transportation of blood may be paid. This is confirmed by the practice of blood and its components sampling. In our opinion, it is necessary to conclude an agreement on the donation of blood and its components, because this type of agreement is not stipulated in any regulatory act.

The parties of the agreement on the blood and its components donation are the donor and the specialized institutions and the blood transfusion institution or relevant departments of health care establishments (blood transfusion stations) 
that sample, process, preserve, use blood and its components. The donor has the exclusive right to blood donation and obligation to report information about his/ her state of health.

The main, most secure and common type of transplantation is the transplantation of organs and tissues from a deceased person, the dead body. Cadaveric transplantation, which is used in most developed countries, is hardly carried out in Ukraine. In our opinion, this is due to the fact that the current regulatory base of Ukraine in the field of transplantation does not fully meet the needs of modern medicine and has many gaps.

From different perspectives, in particular secular and religious, the will of the deceased is compulsory. The religious dogmas, as well as the law prohibit causing damage to the body of a deceased person. Most of the public regards any manipulations with the dead body as abuse or even vandalism. Thus, Article 297 of the Criminal Code of Ukraine prohibits abuse of dead bodies. There is another view on this issue whose supporters claim that it is inappropriate to bury and foredoom to rot organs that could save the lives of many incurables (Chadwick, 1994, p. 57).

As of today, the sphere of legal regulation of relations on implementation of personal intangible rights after the death of the person, who was their holder, is ignored by the lawyers.

A person acquires social value at its birth, and death is the end of the existence of the individual, but after death there is an opportunity for some time to use the physical shell of the deceased person. Noteworthy is the fact that this sphere of human body use is essentially subject to legal regulation within the means of civil character (Punda, 2005).

The problem of implementation of personal intangible rights that were owned by the deceased person is organically linked to the content of a person's intangible right to dignity. For example, the jurisprudence of the Federal Constitutional Court of Germany began the protection of honour of a person after death (although in the literature the dogmatic interpretation of this concept is controversial - while some researchers suggest admitting partial posthumous legal capacity of the deceased person, others trace here the non-subjective right, the monitoring of whose compliance is carried out by the relatives of the deceased) (Shapp, 1996).

At the execution of personal intangible right to health with regard to the donation right it is necessary to conclude an agreement on donation. In particular, it is 
defined lawful to conclude an agreement by the citizen while alive on paid use of their organs, tissues or ashes after death, as well as the possibility of inclusion into the text of the donor's last will the conditions on the order of disposal of the body after death.

Implementation of the personal intangible rights of a deceased person is included in the legislation of other countries, too. For example, in Germany without the given consent by a person while alive or without the close people's consent it is prohibited to use the human body for medical research (Gaskarova, 2002, pp. 154-162). Angela Merkel, by the way, has publicly signed the donor card on the consent of her organs' use.

Thus, some personal intangible rights can be realized after the death of the physical person whom they belonged to, which is associated with preservation of the "legal activity" of this subject of the legal relations and continuation of these relations after the person's death. Such personal intangible rights include the right to donation in regard to donation of anatomical material, received from the dead body of donor.

Using deceased persons' anatomical materials still remains dominant in the transplantation operations. In addition, extraction from the dead donor's body is the only opportunity to get azygos, as the extraction of such organs from a living person would lead to the death of the donor. If we add to this the risk, associated with the operation, which puts the living donor in danger caused by the extraction of an important organ from the body of the deceased, it becomes clear that the modern transplantation medicine really works with cadaverous material (Kobiakov, 2000).

One of the important issues requiring legal regulation is the problem of the legal status of the living donors when taking homotransplants from them. The terms and procedure of taking homotransplants from living donors are regulated by Article 12 of the Law of Ukraine 'On Transplantation of Human Organs and Other Anatomical Materials', according to which taking homotransplants (with the exception of anatomical materials capable of regeneration) from living donors is permitted in cases when the recipient and the donor are married or are close relatives (father, mother, son, daughter, grandfather, grandmother, grandson, granddaughter, brother, sister, uncle, aunt, nephew, niece). According to Article 13 of the Law of Ukraine 'On Transplantation of Human Organs and Other Anatomical Materials' the existence of a donor's voluntary written statement on the consent to take homotransplants from them and on their awareness about the potential consequences is required. 
It should be noted that the list mentioned in the Law of Ukraine 'On Transplantation of Human Organs and Other Anatomical Materials' and in practice causes many complications in the use of this provision of the law. The provision of Article 12 of the above-mentioned law substantially restricts the right of a person to freedom of choice. In addition, the implementation of the donor's rights should be also the freedom in selecting the recipient - the possibility to help a sick person who needs a transplantation of the organ, with whom the donor does not have any family ties.

The exhaustive list of living donors is negatively perceived by organ transplant surgeons, too, because in extreme conditions the compliance with the specified requirement leads to undue loss of a great number of donor organs. In many countries, including the EU, there is so-called moral donation, when a patient who needs transplantation, is given an organ by a soul mate, for example, a godfather. In Belgium, a godfather or godmother are considered close relatives of their godson/daughter. However, to confirm the relationship between people on a religious level, it is necessary to be baptized in Belgium.

The procedure of the withdrawal of consent for donation by the US legislation generates interest. Thus, if the will or other document indicated a specific recipient, the donor may amend or withdraw the consent by means of: (1) a written statement sent to the recipient; (2) an oral statement in the presence of two witnesses and delivered to the recipient; (3) a statement addressed to the doctor and delivered to the recipient; (4) the signed document found with the donor (Margatskaya, 1984).

\section{Conclusions}

According to the statistics of the Ministry of Health of Ukraine, Ukraine ranks last among European countries in terms of post-mortem donation. It is only 0.15 cases per 1 million population in Ukraine, 100 times less than in neighbouring Poland and 230 times less than in Spain. Due to the shortcomings of medical legislation, transplantology (an important branch of medicine) does not have the opportunities for development. As a result, there is an insufficient number of donors in Ukraine, and thousands of sick people are forced to spend huge sums on operations abroad, while even more people die without required funding.

Transplantation is a special type of medical services, which, along with the general rules for the provision of medical services, requires special legislative regulation 
that can take into account all the peculiarities and nuances of this institute. For the emergence of legal relationships in transplantation it is necessary to have a certain legal fact. A legal structure is required for conducting transplantation, in particular, the will of the person who needs the transplantation, on the one hand, and the consent of the medical institution (the transplantation hospital), on the other. In other words, a contractual form based on voluntary informed consent of the patient (the recipient) and the consent of the medical institution is suggested for the legal relationship between the medical institution and the patient in the case of organ transplantation.

A physical person has the right to dispose for the transmission of the organs and other anatomical materials of their body, after death, to scientific, medical, or educational institutions. According to Article 290 of the Civil Code of Ukraine a physical person can give a written consent for donation of their organs and other anatomical materials in case of their death or prohibit it. The legislation does not regulate the content and form of such written instructions of a person about their consent or non-consent to be a donor in case of death.

The purpose of the use of anatomical tissue transplantation is to increase the quality of specialized medical services to the sick, the prolongation of the term of human life, and the reduction of mortality level by large-scale implementation of modern medical technologies. After all, in spite of the achievements of modern medicine, the elimination of danger to life or restoration of the patient's health by other methods is not always possible. Thus, one of the most effective means of achieving such results is the transplantation of anatomical materials. The research of the regulatory base in this sphere is the essential condition for ensuring the rights and interests of donors and patients, who are in need of providing such medical services.

Alla Herts, PhD in Law, is Associate Professor of the Civil Law and Civil Proceedings Department at the Ivan Franko National University of Lviv, in Ukraine. In 2000, Dr. Herts defended her dissertation submitted for the scientific degree of the Candidate of Legal Sciences on the theme Mortgage of an Enterprise as a Single Property Complex at the Ivan Franko National University of Lviv. In 2008, she was awarded with the academic status of the Associate Professor. In 2016, she defended the dissertation submitted for the scientific degree of the Doctor of Law on the theme Contractual Obligations in the Sphere of Medical Services at V. M. Koretskyj Institute of State and Law of NAS of Ukraine. Dr. Herts has published over 90 research works and her research interests are: civil law, contract law, law of obligations, medical law. 


\section{References}

Antipov, N.; Barinov, N. \& Bykova, T. (1998), Civil Law of Russia. Part One. Textbook, Moscow: Yurist Press.

Chadwick, R. F. (1994), 'Corpses, recycling and therapeutic purposes,' Death Rites: Law and Ethics at the End of Life, London \& New York: Routledge, pp. 57-72.

Civil Code of Ukraine (2003), Bulletin of the Supreme Council of Ukraine (BSC), 16.01.2003, 435-IV, 40-44, 356. Retrieved from http://zakon5.rada.gov.ua/laws/ show/435-15 [accessed 12 Mar 2018]

Convention for the Protection of Human Rights and Dignity of the Human Being with regard to the Application of Biology and Medicine: the Convention on Human Rights and Biomedicine (1997). Retrieved from http://zakon2.rada.gov.ua/laws/ show/994_334 [accessed 12 Mar 2018]

Declaration concerning the human organs transplantation (1987). Retrieved from http://zakon2.rada.gov.ua/ [accessed 12 Mar 2018]

Directive 2004/23/EU on setting standards of quality and for the donation, procurement, testing, processing, preservation, storage and distribution tissues and cells (2004), European Parliament and the Council of the European Union. Retrieved from http:// www.transplant-observatory.org/download/directive-200423ec-of-the-europeanparliament-and-of-the-councilof-31-march-2004-on-setting-standards-ofquality-and-safety-for-the-donation-procurement-testing-processingpreservationstorage-a/ [accessed 12 Mar 2018]

Gaskarova, M. (2002), 'Concept of human dignity in German constitutional law,' Journal of Russian Law, no. 4, pp. 154-162. Retrieved from http://www.law.edu. $\mathrm{ru} /$ article/article.asp?articleID=171621 [accessed 12 Mar 2018]

Kerikmäe, T.; Hamulak, O. \& Chochia, A. (2016), 'A historical study of contemporary human rights: deviation or extinction?' Acta Baltica Historiae et Philosophiae Scientiarum, vol. 4, no. 2, pp. 98-115. https://doi.org/10.11590/abhps.2016.2.06

Kobiakov, D. (2000), Legal Problems of Transplantology, PhD dissertation, Institute of State and Law, Russian Academy of Sciences, Moscow: House Publishing of Institute of State and Law. Retrieved from http://law.edu.ru/book/book. asp?bookID=89862 [accessed 12 Mar 2018]

Law of Ukraine 'On the Blood and Blood Components Donation' (1995), Bulletin of the Supreme Council of Ukraine (BSC), 23.06.1995, 23, 183. Retrieved from http://zakon3.rada.gov.ua/laws/show/239/95-вр [accessed 12 Mar 2018]

Law of Ukraine 'On transplantation of human organs and other anatomical material' (1999), Bulletin of the Supreme Council of Ukraine (BSC), 16.07.1999, 1007-XIV, 41, 377. Retrieved from http://zakon5.rada.gov.ua/laws/show/1007-14 [accessed 12 Mar 2018] 
Margatskaya, N. (1984), Civil Problems of Donation and Transplantation. PhD dissertation Moscow State University named after M. V. Lomonosov, Moscow: House Publishing of Moscow State University named after M. V. Lomonosov. Retrieved from http://law.edu.ru/book/book.asp?bookID=69142 [accessed $12 \mathrm{Mar}$ 2018]

Moiseieva, T. (2015), 'Will oxygen be administered at transplantation?' Government Courier, 31 July 2015. Retrieved from https://ukurier.gov.ua/uk/articles/chipodadut-kisen-transplantologiyi [accessed 12 Mar 2018]

'On the Transplantation of Human Organs and Tissue' (1997), Law of the Republic of Belarus, 04 March 1997, 28-3. Retrieved from http://www.base.spinform.ru/ show_doc.fwx?rgn=2036 [accessed 12 Mar 2018]

'On Transplantation of Human Organs and Other Anatomical Materials' (2015), The Draft Law of Ukraine, No. 2386a-1 of 04.08.2015. Retrieved from http://w1.c1. rada.gov.ua/pls/zweb2/webproc4_1?pf3511=56231 [accessed 12 Mar 2018]

Order of the Ministry of Health of Ukraine (2000), Approving Instructions on extraction of human organs from a donor-dead body, 2000, 226. Retrieved from http:// mozdocs.kiev.ua/ [accessed 12 Mar 2018]

Order of the Ministry of Health of Ukraine (2006), On the Approval of the Regulation on the Coordination Centre for the Transplantation of Organs, Tissues and Cells, 2006, 812. Retrieved from http://zakon4.rada.gov.ua/laws/show/z1380-06 [accessed 12 Mar 2018]

Provision on sale of live organs adopted by the 37th World Medical Assembly Brussels (1985). Retrieved from http://zakon2.rada.gov.ua/laws/show/990_024 [accessed 12 Mar 2018]

Ptashnyk, I. (2016), Civil Law Regulation of Transplantation in Ukraine. Dissertation Research Institute of Private Law and Entrepreneurship named after Academician F.G. Burchak of the National Academy of Legal Sciences of Ukraine, PhD thesis, Kyiv: House Publishing of Research Institute of Private Law and Entrepreneurship named after Academician F. G. Burchak of the National Academy of Legal Sciences of Ukraine. Retrieved from https://drive.google.com/file/d/0B6e_r dbLQfjc3B3M1J1UTJtVjQ/view [accessed 12 Mar 2018]

Punda, O. (2005), Concepts and Problems of Implementation of Personal Intangible Rights that Provide Natural Human Existence, Kyiv: Publishing House of Serhii Pantiuk.

Pynes, S. (2009), 'Human Cloning: Legal Aspects,' Macomb: Western Illinois University. https://doi.org/10.1002/9780470015902.a0005200.pub2

Shapp, Y. (1996), Fundamentals of the Civil Law of Germany, Moscow: BEK. Retrieved from http://www.law.edu.ru/doc/document.asp?docID=1118593 [accessed 12 Mar 2018] 
Volkova, A. (2011), 'Legal aspects of regulation of transplantation in modern legal practice,' Bulletin of Kharkiv National University after named V. N. Karazin, no. 938, pp. 100-105. Retrieved from http://periodicals.karazin.ua/medicine/article/ download/3389/2962\# page=101 [accessed 12 Mar 2018]

Voloshyn, N. \& Ryasentsev V. (1987), Soviet Civil Law, Moscow: Yuridicheskaya Literatura.

Welser, R. \& Rabl, C. (2004), Produkthaftungsgesetz. Kommentar, Wien: Lexis Nexis ARD Orac Press. Retrieved from http://heinonline.org/HOL/ LandingPage?handle=hein.kluwer/asab0027\&div=22\&id=\&page [accessed 12 Mar 2018] 